\title{
Tinjauan Literatur
}

\section{PERAN ASTAXANTHIN PADA LUKA BAKAR}

\author{
Nathasia Ayunda Pardina ${ }^{\star 凶}$, Lita Setyowatie*
}

\begin{abstract}
Abstrak
Luka bakar merupakan kerusakan pada kulit yang disebabkan oleh panas berlebihan atau bahan kimia kaustik. Beberapa faktor seperti iskemia, stres oksidatif, inflamasi, dan kematian sel (nekrosis atau apoptosis), berkontribusi pada konversi luka bakar dini, yang merupakan perubahan progresif pada zona peri lesi yang mencakup zona stasis dan hiperemia. Meskipun inflamasi merupakan faktor penting dalam penyembuhan luka, namun juga dapat menghambat proses penyembuhan. Reaksi inflamasi akut berkepanjangan didominasi oleh neutrofil dan makrofag, dapat menyebabkan peningkatan level sitokin proinflamasi, yang mengakibatkan degradasi kolagen dan apoptosis keratinosit, perlekatan neutrofil pada endotel vena menghasilkan mikrovaskular yang berbahaya, dan produksi oksigen radikal bebas yang mengakibatkan gangguan membran plasma, ikatan silang dan putusnya ikatan DNA, serta fragmentasi peptida. Stres oksidatif pada luka bakar dapat ditekan dengan senyawa antioksidan seperti astaxanthin. Astaxanthin merupakan antioksidan alami yang memberikan efek perlindungan melawan konversi luka bakar dengan menurunkan stres oksidatif terkait radikal bebas, meredakan inflamasi pada tahap awal luka bakar dan mengurangi apoptosis sel di zona stasis. Oleh karena, perlu diulas lebih lanjut mengenai peran astaxanthin pada luka bakar.
\end{abstract}

Kata kunci : antioksidan, astaxanthin, luka bakar.

\section{ROLE OF ASTAXANTHIN IN BURNS}

\begin{abstract}
Burns are damage skin caused by excessive heat or caustic chemicals. Several factors, such as ischemia, oxidative stress, inflammation, and cell death (necrosis or apoptosis), are contribute to early burn conversion, which is a progressive change in the peri lesion zone which includes the zone of stasis and hyperemia. Although inflammation is an important factor in wound healing, it can also inhibit the healing process. Prolonged acute inflammatory reactions dominated by neutrophils and macrophages, can cause an increase in proinflammatory cytokine levels, which results in degradation of collagen and apoptosis of keratinocytes, attachment of neutrophils to venular endothelium resulting in dangerous microvascular conditions, and the production of free radical oxygen resulting in disruption of plasma membranes, crosslinking and breakdown of keratinocytes DNA binding, as well as peptide fragmentation. The oxidative stress in burns can be supressed by antioxidant agent such as astaxanthin. Astaxanthin is a natural antioxidant that provides a protective effect against burn conversion by reducing oxidative stress related to free radicals, relieving inflammation in the early stages of burns and reducing cell apoptosis in the stasis zone. Therefore, it is necessary to discuss further about the role of astaxanthin in burns.
\end{abstract}

Keywords: antioxidant, astaxanthin, burns.

* Departemen/SMF Dermatologi dan Venereologi, Fakultas Kedokteran, Universitas Brawijaya-RSUD dr. Saiful Anwar, Malang

E-mail: nathasia.saschya@gmail.com 


\section{Pendahuluan}

Cedera akibat luka bakar relatif umum terjadi di seluruh dunia. Diperkirakan lebih dari 500.000 orang datang ke unit gawat darurat di Amerika Serikat karena mengalami luka bakar setiap tahunnya. Sebagian besar adalah luka bakar ringan dan sekitar 40.000 pasien membutuhkan rawat inap. Luka bakar paling umum terjadi pada anak-anak, $80 \%$ sering akibat kontak dengan benda atau cairan panas. Selain itu, orang yang berusia tua juga merupakan kelompok yang berisiko tinggi mengalami luka bakar. ${ }^{1}$ Data dari Unit Luka Bakar Rumah Sakit Saiful Anwar, terdapat 177 kasus luka bakar dengan angka kematian 13\% pada tahun 2018 dan 181 kasus luka bakar dengan angka kematian sebesar 17\% pada tahun 2019 (data tidak dipublikasikan).

Kemajuan luar biasa telah dibuat dalam pengelolaan luka bakar pada dekade terakhir. Morbiditas dan mortalitas telah sangat berkurang karena perbaikan dalam perawatan kritis, dukungan metabolisme, pengendalian infeksi, dan manajemen luka yang tepat. ${ }^{2}$ Proses penyembuhan luka bakar sangat kompleks. Jika dibandingkan dengan luka jenis lain, kerusakan jaringan pada luka bakar menghasilkan radikal bebas yang lebih tinggi sehingga dapat mengakibatkan terjadinya stres oksidatif akibat gangguan keseimbangan antara radikal bebas dengan antioksidan. Stres oksidatif tersebut dapat memperlambat proses penyembuhan luka bakar. ${ }^{3}$ Konsentrasi radikal bebas yang rendah diperlukan untuk memulai proses perbaikan normal. Antioksidan diperlukan untuk menunjang proses ini dengan menghambat reaksi oksidasi dengan mengikat radikal bebas dan molekul yang sangat reaktif sehingga kerusakan sel akan terhambat. ${ }^{4}$ Astaxanthin (AST), yang diekstraksi dari beberapa organisme laut, adalah senyawa alami dengan efek antioksidan kuat diduga dapat berperan dalam proses penyembuhan luka pada luka bakar. ${ }^{2}$ Dalam tinjauan pustaka ini akan dibahas mengenai peran astaxanthin pada luka bakar.

\section{Luka Bakar}

\section{a. Definisi}

Luka bakar didefinisikan sebagai kerusakan pada kulit yang disebabkan oleh panas berlebihan atau bahan kimia kaustik. Luka bakar yang paling umum merupakan hasil dari paparan panas dan bahan kimia. Luka bakar full-thickness biasanya berkembang, menyebabkan kematian sel dan kerusakan matriks, dengan kerusakan terparah ada di permukaan luka. Panas dan inflamasi menginduksi cedera jaringan di bawah permukaan yang nonviabel, yang dapat berkembang dari waktu ke waktu menjadi sembuh atau dapat memburuk menjadi nekrosis lebih lanjut, tergantung pada te-rapi yang diberikan. ${ }^{5}$

\section{b. Kedalaman Luka Bakar}

Luka bakar bersifat dinamis dan dapat berkembang menjadi cedera yang lebih dalam dari waktu ke waktu, tergantung pada cedera awal dan faktor lingkungan selanjutnya. Luka bakar tersusun atas lapisan luar jaringan yang nonviabel, yang dikenal sebagai zona nekrosis. Hal ini melibatkan kedua lapisan kulit pada luka bakar full-thickness. Pada luka bakar partial-thickness, jaringan yang viabel di bawah lapisan nekrosis masih terluka, dikenal sebagai zona cedera dan bisa menjadi nonviabel dari waktu ke waktu, tergantung pada tingkat cedera dan faktor selanjutnya, seperti infeksi. Proses ini dikenal sebagai konversi luka. ${ }^{1}$

\section{c. Derajat Luka Bakar}

- Luka Bakar Superfisial (Derajat Satu)

Luka bakar derajat pertama hanya melibatkan epidermis, seperti sengatan matahari, hangat, lesi tampak eritematosa, nyeri, pucat, dan kering tanpa lecet. Epitel akibat luka bakar derajat pertama biasanya tetap utuh , 
namun akan mulai mengelupas dalam waktu 7 sampai 14 hari. Kerusakan jaringan jangka panjang jarang ditemui. 6,7

- Luka Bakar Superfisial Partial-Thickness (Derajat Dua Superfisial)

Luka bakar derajat dua superfisial melibatkan semua epidermis dan sebagian dari dermis di bawahnya. Luka bakar parsial merusak lapisan atas papilari dermis, lesi diidentifikasi sebagai lepuhan yang jernih, basah, eritematosa, nyeri, dan blanchable ketika disentuh. Luka bakar ini sembuh dalam waktu dua minggu dan umumnya tidak menyebabkan jaringan parut. Namun, jaringan parut dan perubahan pigmen masih mungkin terjadi. 6

- Luka Bakar Deep Partial-Thickness (Derajat Dua Dalam)

Luka bakar tingkat dua yang dalam melibatkan lapisan dermis yang lebih dalam (misalnya dermis reticular). Lesi tampak putih dan nonblanchable. Luka bakar ini tidak sembuh dalam waktu kurang dari tiga minggu dan sering mengakibatkan jaringan parut dan kontraktur. 6

- Luka Bakar Full-Thickness (Derajat Tiga)

Luka bakar derajat tiga merusak seluruh lapisan kulit, termasuk lemak subkutan di bawahnya. Warnanya coklat tua atau tan dan terasa kasar, tidak sensitif terhadap sentuhan. Luka ini sering membutuhkan skin graft, dan bisa mengakibatkan kontraktur. ${ }^{6}$

- Luka Bakar Derajat Empat

Luka bakar derajat empat merusak semua lapisan kulit dan meluas hingga ke dalam otot, tendon, atau tulang. Hal ini menyebabkan hilangnya rasa pada area tersebut karena kerusakan pada ujung saraf. 6,7
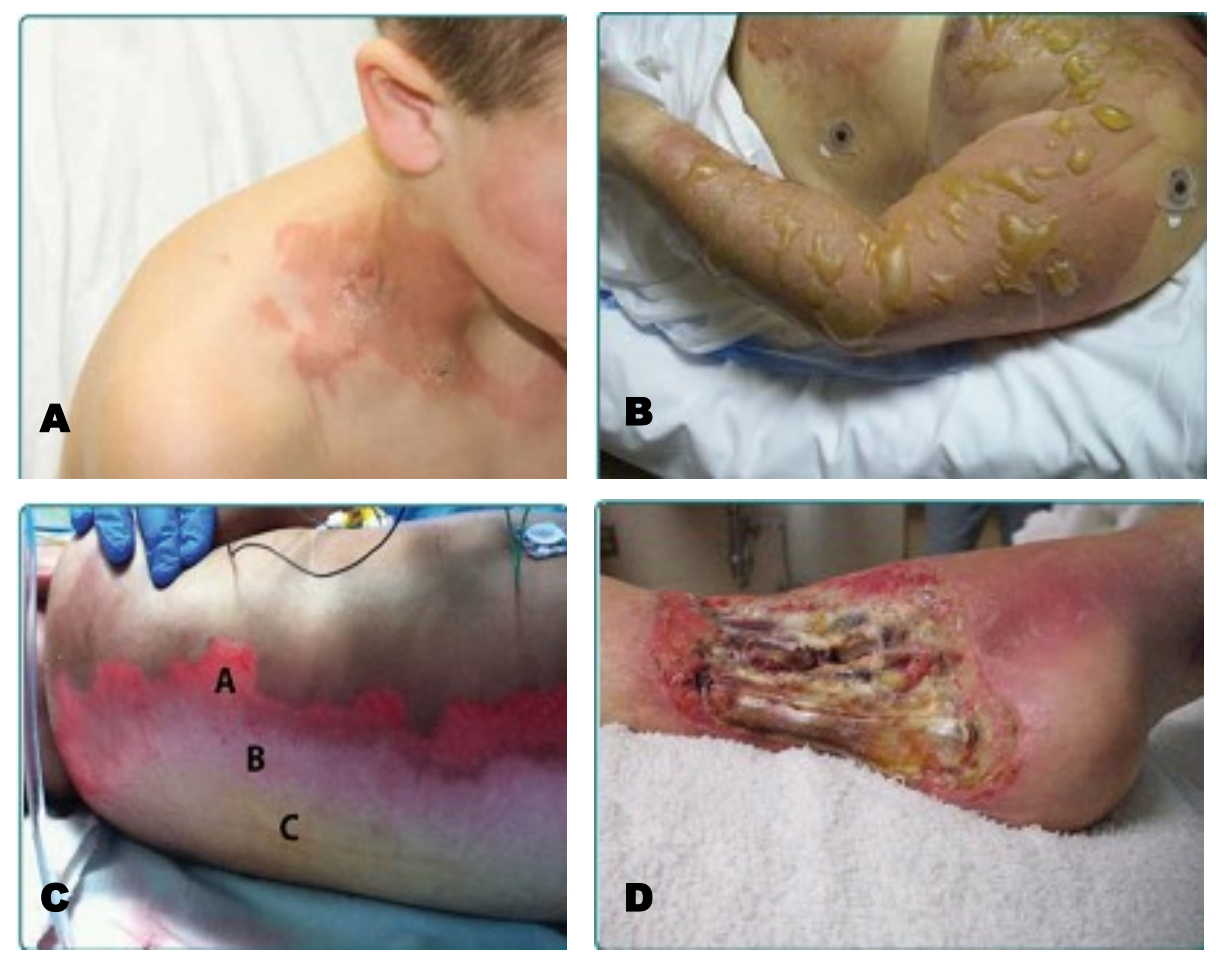

Gambar 1. Gambaran klinis luka bakar.

Keterangan: (A) Luka bakar superfisial, tampak patch eritematus dan kering. (B) Luka bakar partialthickness, tampak bulat berisi cairan jernih dengan dasar eritematus. (C). Luka bakar fullthickness, tampak erosi dengan dasar eritematus. (D) Luka bakar derajat empat, tampak luka bakar meluas hingga ke dalam otot, tendon dan tulang. 6 


\section{d. Ukuran Luka Bakar}

Pengukuran luas luka bakar bisa menggunakan Klasifikasi Lund-Browder atau "Rule of Nines". Klasifikasi Lund-Browder dapat digunakan untuk penilaian awal ukuran luka bakar pada orang dewasa atau anakanak. Diagram " Rule of Nines " sangat membantu untuk mempercepat penilaian ukuran luka bakar, tetapi metode ini kurang akurat daripada klasifikasi Lund-Browder, terutama pada anak-anak (Gambar 2). Tangan sering digunakan untuk mengukur area terbakar kecil, yang berkorelasi dengan 1 persen dari total luas permukaan tubuh. Studi telah menunjukkan bahwa tangan orang dewasa lebih mendekati $0,8 \%$ dari total luas permukaan tubuh, sedangkan tangan anak-anak sekitar $1 \% .{ }^{1}$

\section{e. Patofisiologi Luka Bakar}

Mediator lokal yang dihasilkan pada luka bakar adalah histamin, serotonin, bradikinin, nitric oxide, oksigen radikal bebas dan produk kaskade asam eikosanoid (prostaglandin, tromboksan), tumour necrosis factor (TNF), interleukin. Histamin adalah mediator yang paling bertanggung jawab pada fase awal dari meningkatnya permeabilitas mikrovaskuler yang terlihat segera setelahnya luka bakar. Histamin menyebabkan celah endotel yang besar untuk bentuk sementara sebagai akibat dari kontraksi sel endotel venular. Beberapa studi menunjukkan bahwa patogenesis edema luka bakar pada kulit tampaknya terkait dengan interaksi histamin dengan xanthin oksidase dan oksigen radikal. Perubahan lokal pada luka bakar diklasifikasikan oleh Jackson menjadi tiga zona. ${ }^{5}$

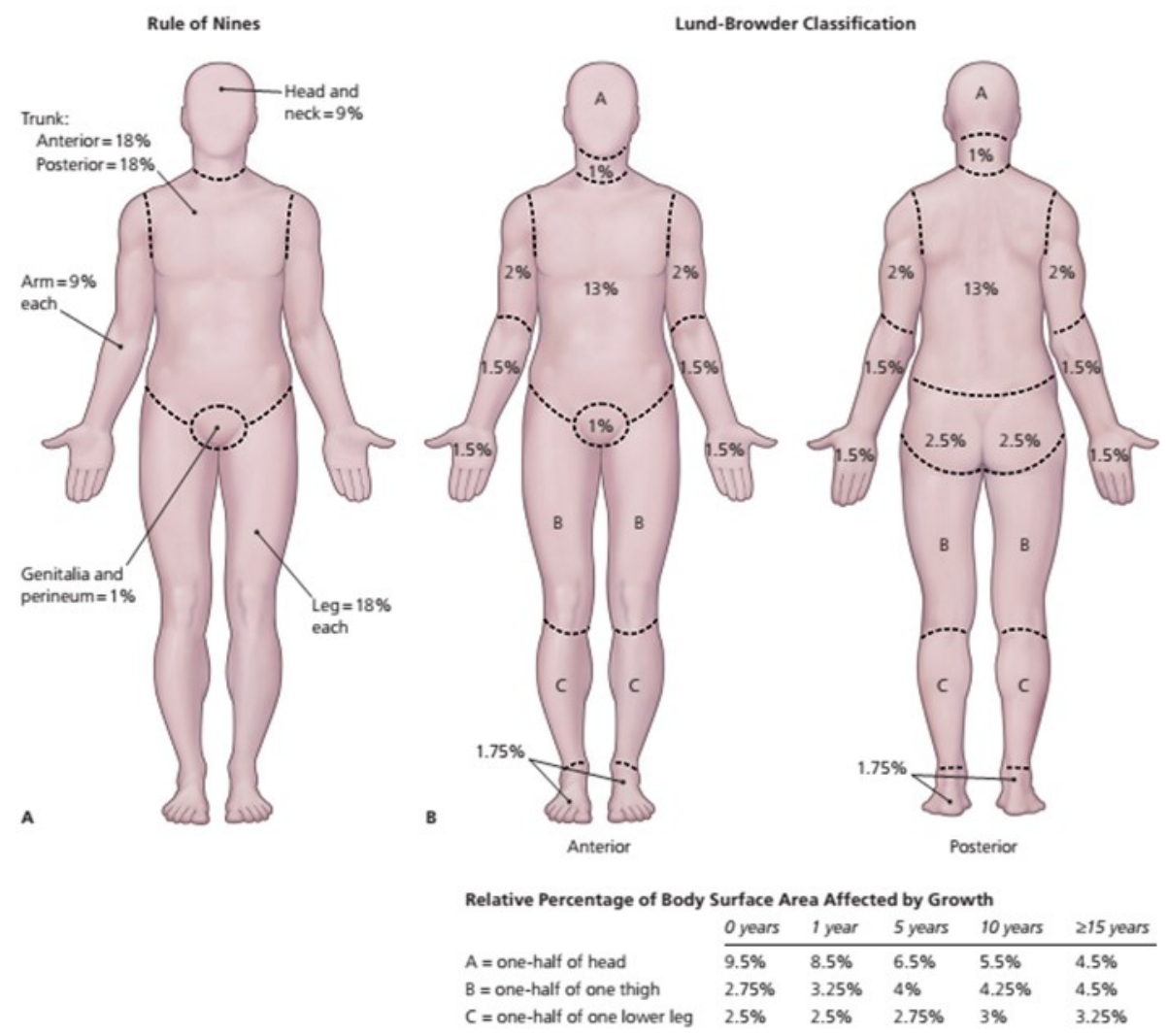

Gambar 2. Diagram untuk menilai luas luka bakar.

Keterangan: (A) Rule of Nine membagi tubuh menjadi 9 atau $18 \%$ dari total body surface area (BSA). (B) Klasifikasi Lund-Browder lebih akurat untuk menilai ukuran luka bakar, khususnya pada

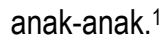


Jackson (1953) menggambarkan tiga zona konsentris luka bakar yaitu zona pusat koagulasi, zona tengah stasis, dan zona luar hiperemia (Gambar 3). Jaringan putih di zona koagulasi mengalami kerusakan langsung terbesar dari trauma termal dan ditandai dengan nekrosis ireversibel. Secara mikroskopis, zona koagulasi menunjukkan penghancuran total vaskular subpapiler. Sebaliknya, jaringan edematosa dan merah di zona hiperemia selalu pulih. Jackson menyatakan riwayat alami zona stasis melibatkan penghentian total aliran darah dalam waktu 24 jam dan nekrosis jaringan, sehingga zona stasis dan koagulasi menjadi tidak dapat dibedakan.8,9

Pada tahun 1969, setelah mengamati kemampuan zona stasis untuk menerima autograft dan berdarah dari beberapa arteriol pada eksisi, Jackson menyadari bahwa zona stasis tidak avaskular dan mungkin tidak "mati." Serta, mencatat bahwa lapisan kulit yang sama mampu menerima dan mendukung graft menjadi brown dry slough tanpa adanya okulasi. Kemampuan untuk menghentikan kerusakan jaringan di zona stasis dapat secara signifikan mempengaruhi keseluruhan kedalaman dan luas permukaan luka bakar, yang sering terus mengalami

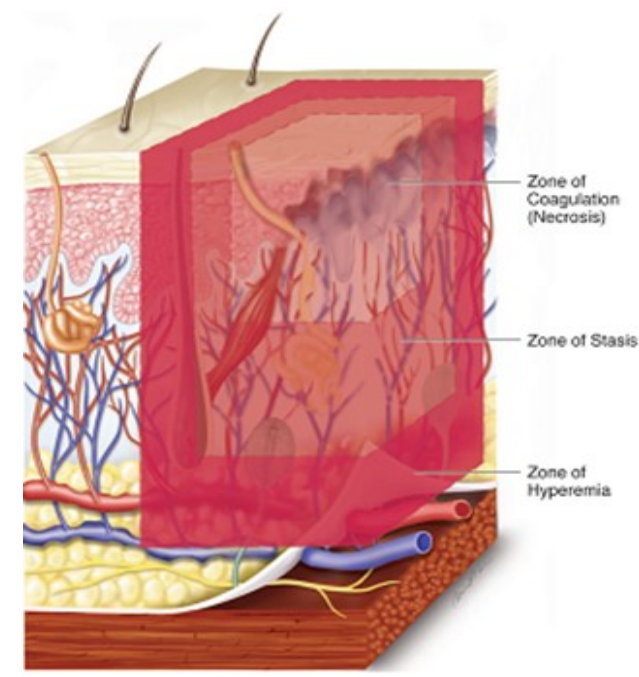

kemajuan selama 2 minggu setelah kejadian awal yang merugikan. Luasnya permukaan yang terlibat dan kedalaman luka bakar merupakan penentu utama mortalitas dan morbiditas, berkorelasi dengan tingkat penyembuhan luka yang tertunda, skar hipertrofik, dispigmentasi, kontraktur, infeksi, dan syok. ${ }^{9}$

\section{f. Mekanisme Penyembuhan Luka Setelah Luka Bakar}

Cedera luka bakar yang parah diikuti oleh respons inflamasi yang berat. Luka bakar mengandung berbagai jenis sel termasuk trombosit, neutrofil, limfosit, makrofag dan fibroblas, yang aktivitasnya diatur oleh interaksi yang kompleks dari beberapa sitokin serta mekanisme neuroendokrin. Regulator molekul utama yang mengendalikan evolusi luka bakar termasuk vascular endothelial growth factor (VEGF), platelet-derived growth factor (PDGF) dan transforming growth factorß (TGF-ß). Transforming growth factor (TGF)beta sangat penting untuk aktivasi dan proliferasi fibroblast selama tahap awal penyembuhan luka. Aktivitas berkelanjutan dari TGF-beta dikaitkan dengan skar hipertrofi dan kontraksi luka yang mengakibatkan deformitas. $^{9}$

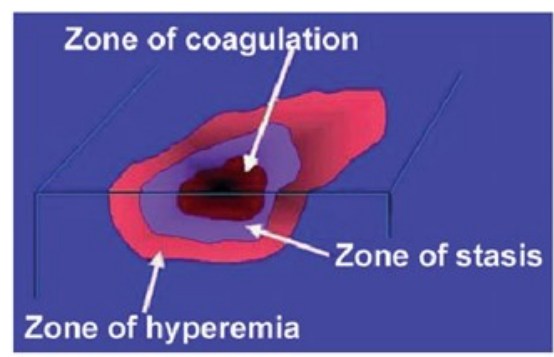

Gambar 3. Zona luka bakar.

Keterangan: Tiga zona konsentris luka bakar di antaranya zona koagulasi, zona stasis, dan zona hiperemia. 5,9 


\section{g. Apoptosis dan Onkosis pada Luka Bakar}

Untuk lebih memahami dasar seluler perkembangan luka bakar, sejumlah studi telah memeriksa mekanisme kematian sel di zona stasis. Gravante et al (2006) meneliti apoptosis pada luka bakar deep partialthickness manusia. Penelitian tersebut menemukan bahwa $44 \%$ sel kulit pada luka bakar mengalami apoptosis, dan keberadaan sel apoptosis bertahan hingga 13 hari setelah cedera luka bakar. ${ }^{10}$ Gravante et al (2008) menemukan bahwa apoptosis tingkat tertinggi awal setelah luka bakar tetapi bertahan selama 23 hari. Penelitian tersebut juga menemukan bahwa tingkat apoptosis tidak berkorelasi dengan mortalitas, seperti luka bakar yang tidak selamat menunjukkan tingkat apoptosis yang lebih rendah $(30,1 \%)$ dibandingkan yang selamat $(44,0 \%)$. $^{9-11}$

Secara keseluruhan, penelitian oleh Gravante et al memungkinkan tiga kesimpulan yaitu: 1) sel-sel kulit yang mengalami apoptosis ditemukan pada tingkat yang lebih tinggi pada luka bakar deep partial-thickness daripada kulit normal, luka bakar superfisial partial-thickness, dan luka bakar fullthickness, tetapi tidak mengkonfirmasikan bahwa apoptosis berperan dalam progresi luka deep partial-thickness; 2) apoptosis berlanjut setidaknya selama 23 hari setelah cedera awal luka bakar, memberikan peluang besar bagi intervensi farmakologis; dan 3) tingkat apoptosis tidak terpengaruh oleh indeks prognostik mortalitas pasien, menyiratkan bahwa proses lokal mungkin lebih penting daripada kondisi sistemik dalam mempengaruhi apoptosis di zona stasis. Namun, satu batasan dari studi ini adalah kegagalan secara definitif untuk menunjukkan hubungan antara laju apoptosis dan evolusi luka bakar deep partial-thickness hingga luka bakar full-thickness. ${ }^{9}$

\section{h. Luka Bakar dan Infiltrasi Sel Inflamasi Inflamasi merupakan faktor penting dalam penyembuhan luka, tetapi juga dapat}

menghambat proses penyembuhan. Efek menguntungkan dari inflamasi lokal termasuk pembersihan debris seluler dan perlindungan dari agen mikroba. Namun, reaksi inflamasi akut berkepanjangan didominasi oleh neutrofil dan makrofag, dapat menyebabkan peningkatan level sitokin proinflamasi, yang mengakibatkan degradasi kolagen dan apoptosis keratinosit, perlekatan neutrofil pada endotel venular menghasilkan mikrovaskular yang berbahaya, dan produksi oksigen radikal bebas yang mengakibatkan gangguan membran plasma, ikatan silang dan putusnya ikatan DNA, serta fragmentasi peptida. ${ }^{9}$

\section{i. Luka Bakar dan Radikal Bebas}

Radikal bebas adalah molekul dengan bagian luar yang tidak berpasangan mengorbit elektron yang memiliki oksidasi kuat atau mengurangi kapasitas. Reactive oxygen species (ROS) mengacu pada kedua radikal bebas dan molekul lain yang terlibat dalam produksi radikal bebas. Reactive oxygen species yang terkenal adalah superoksida $\left(\mathrm{O}_{2}{ }^{-}\right)$, hidrogen peroksida $\left(\mathrm{H}_{2} \mathrm{O}_{2}\right)$, dan radikal hidroksil $\left(\mathrm{OH}^{\circ}\right)$. Dalam kondisi normal, metabolisme sel menghasilkan ROS sebagai produk sampingan dari fosforilasi oksidatif dalam mitokondria, oksidasi purin oleh xanthine oxidase, aktivasi neutrofil dari sistem oksidase yang tergantung nicotinamide adenine dinucleotide phosphate (NADPH), dan pembagian asam arakidonat menjadi prostaglandin dan leukotrien. ${ }^{9}$

Antioksidan adalah senyawa atau sistem enzim yang memerangi kerusakan potensial seluler yang dihasilkan dari ROS. Contoh antioksidan di antaranya superoksida dismutase (SOD), katalase, glutathione peroxidase, tocopherol (vitamin E), asam askorbat (vitamin C), dan glutathione. Ketika ada ketidakseimbangan ROS dibandingkan dengan antioksidan, sistem biologis berada di bawah tekanan oksidatif. 
Mekanisme dimana stres oksidatif dapat berkontribusi pada kerusakan jaringan progresif di zona stasis termasuk peroksidasi lipid dari membran sel dan gangguan protein dan asam nukleat, yang berujung pada kematian sel. ${ }^{9}$

\section{Astaxanthin}

\section{a. Definisi}

Xantofil merupakan kelompok utama karotenoid yang meliputi astaxanthin (ATX), $\beta$ -cryptoxanthin, canthaxanthin, lutein, dan zeaxanthin. Struktur kimianya tampak pada Gambar 4.12 Astaxanthin (ATX) adalah turunan karotenoid yang mengandung oksigen, pigmennya berwarna merah-oranye dan larut dalam lemak. ${ }^{13}$ Astaxanthin dapat diekstraksi dari berbagai mikroorganisme, fitoplankton, hewan laut, dan makanan laut seperti udang, lobster, asteroidean, ganggang, ikan, krustasea, trout, krill, ikan air tawar dan salmon. Mikroalga Haematococcus pluvialis adalah sumber utama ATX untuk konsumsi manusia dan memiliki potensi terbesar untuk menyediakan ATX.
Astaxanthin juga ditemukan dalam ragi Xanthophyllomyces dendrorhous (sebelumnya dikenal sebagai Phaffia rhodozyma), pada tanaman, beberapa jamur, Chlorococcum sp, Chlorella zofingiensis, dan bakteri laut Agrobacterium aurantiacum. ${ }^{14}$

\section{b. Aktivitas Antioksidan Astaxanthin}

Stres oksidatif sebagai mediator utama dalam patologi penyakit, disebabkan oleh gangguan status keseimbangan reaksi prooksidan/antioksidan dalam sel. Stres oksidatif mempercepat produksi ROS dan radikal bebas. Astaxanthin bertindak sebagai perlindungan terhadap kerusakan oksidatif melalui perbedaan mekanisme seperti menetralkan oksigen tunggal, mengambil radikal untuk mencegah reaksi berantai, pemeliharaan struktur membran melalui penghambatan peroksidasi lipid (LPO), peningkatan fungsi sistem kekebalan tubuh dan regulasi ekspresi gen. Bahkan, rantai poliena ATX menangkap radikal di membran sel, sedangkan cincin terminal ATX mencari radikal di luar dan di dalam membran sel.

\section{(a)}

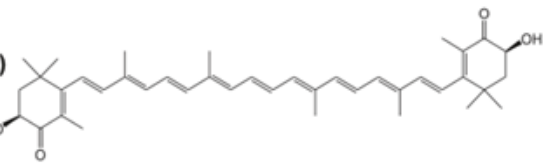

(b)

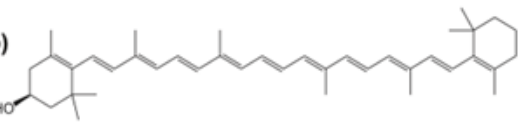

(c)

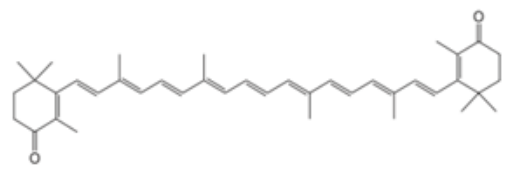

(d)

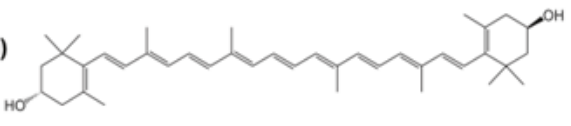

(e)

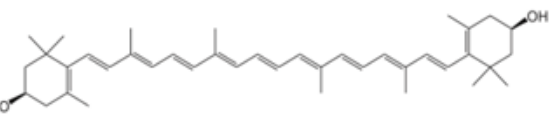

Gambar 4. Struktur kimia astaxanthin.

Keterangan: (a). $\beta$-cryptoxanthin, (b). Canthaxanthin, (c). Lutein, (d). dan zeaxanthin (e).12 
Kapasitas antioksidan yang tinggi dan gambaran kutub ATX membuatnya menjadi nutraceutical luar biasa yang menguntungkan untuk nutrisi manusia dan layanan kesehatan. ${ }^{15}$ Dibandingkan dengan antioksidan lainnya, aktivitas antioksidan ATX 100 kali lebih besar dari vitamin $\mathrm{E}$ yang telah terpapar LPO dan sekitar 550 kali lebih mampu dalam menetralkan oksigen tunggal dibandingkan vitamin E. Aktivitas antioksidannya 100-1000 kali lipat lebih tinggi daripada agen fotokimia lainnya, dan 100 kali lipat lebih banyak dari atokoferol, zeaxanthin, lutein, canthaxanthin dan $\beta$-karoten. ${ }^{16,17}$

\section{c. Aktivitas Antiinflamasi Astaxanthin}

Inflamasi adalah urutan respons imun kompleks yang terjadi sebagai mekanisme pertahanan host atau reaksi terhadap cedera tubuh untuk memulai proses perbaikan jaringan. Namun, inflamasi yang berlebihan atau tidak terkontrol berbahaya bagi host dan dapat merusak sel dan jaringan host. Inflamasi berperan penting dalam kondisi neurodegeneratif akut dan kronis. Astaxanthin adalah antioksidan kuat yang mampu menghentikan timbulnya inflamasi dalam sistem biologis. Efek antiinflamasi ATX berperan penting dalam mencegah perkembangan gangguan sistem saraf pusat dan efek biologisnya. Astaxanthin memblokir jalur pensinyalan nuclear factor kappa $B$ (NF-kB); dan mencegah ekspresi gen mediator inflamasi seperti interleukin-1 $\beta$ (IL-1 $\beta$ ), interleukin-6 (IL-6) dan tumor necrosis factor-a (TNF-a). Dalam kondisi normal, NF-kB tetap tidak aktif dalam sitosol, hal ini disebabkan interaksi dengan inhibitor kappa B (IKB) sebagai inhibitor utamanya. Stimulasi NF-kB mempercepat fosforilasi IkB oleh IkB kinase $\beta$ (IKK $\beta$ ). Stimulasi juga menurunkan IKB melalui jalur proteasome ubiquitin, serta menginduksi disosiasi IKB dari NF-KB, dan mengekspos sinyal lokalisasi nuclear pada NF-kB. Akibatnya, stimulasi yang diinduksi ini akan menyebabkan proses $\mathrm{IKB}$ yang meregulasi transkripsi gen inflamasi. Astaxanthin juga menunjukkan aktivitas antiinflamasi dengan menghambat enzim siklooksigenase-1 (COX1) dan nitrat oksida (NO) pada sel mikroglial BV2 yang distimulasi lipopolisakarida. Studi in vivo juga menunjukkan bahwa ATX memiliki kemampuan untuk menurunkan inflamasi jaringan dan organ. 15

\section{d. Aktivitas Antiapoptosis Astaxanthin}

Astaxanthin dapat memberikan efek antiapoptosis atau proapoptosis tergantung pada kondisi patologis. Banyak protein kunci apoptosis yang terlibat dalam dua jalur apoptosis utama, yaitu intrinsik (jalur mitokondria) dan ekstrinsik (jalur reseptor kematian). Astaxanthin dapat memodifikasi beberapa protein kunci apoptosis dan mencegah penyakit terkait. Astaxanthin telah dilaporkan meningkatkan fosforilasi $\mathrm{Bcl}-2$ associated death molecule (BAD) dan juga mengatur aktivasi sitokrom $C$ dan caspase 3 dan 9 melalui regulasi protein kinase yang diaktifkan mitogen/p38 (p38 MAPK). Astaxanthin juga mengaktifkan jalur survival PI3K/AKT, yang memperbaiki apoptosis terkait mitokondria. ${ }^{18}$

\section{e. Peran Astaxanthin pada Luka Bakar}

Setelah terjadi luka bakar, beberapa faktor seperti iskemia, stres oksidatif, inflamasi, dan kematian sel (nekrosis atau apoptosis), berkontribusi pada konversi luka bakar dini, yang merupakan perubahan progresif pada zona perilesi yang mencakup zona stasis dan hiperemia. Konversi mungkin mengarah pada kedalaman atau perluasan dari lokasi inisiasi. Mengingat serangkaian kejadian setelah perkembangan luka bakar, seperti skar hipertrofi, kontraktur luka, infeksi, dan sepsis, menarik minat penulis untuk mencari intervensi yang tepat. Mempertimbangkan efek yang dilaporkan pada stres oksidatif, apoptosis dan inflamasi, astaxanthin bermanfaat selama transformasi pada zona stasis. 


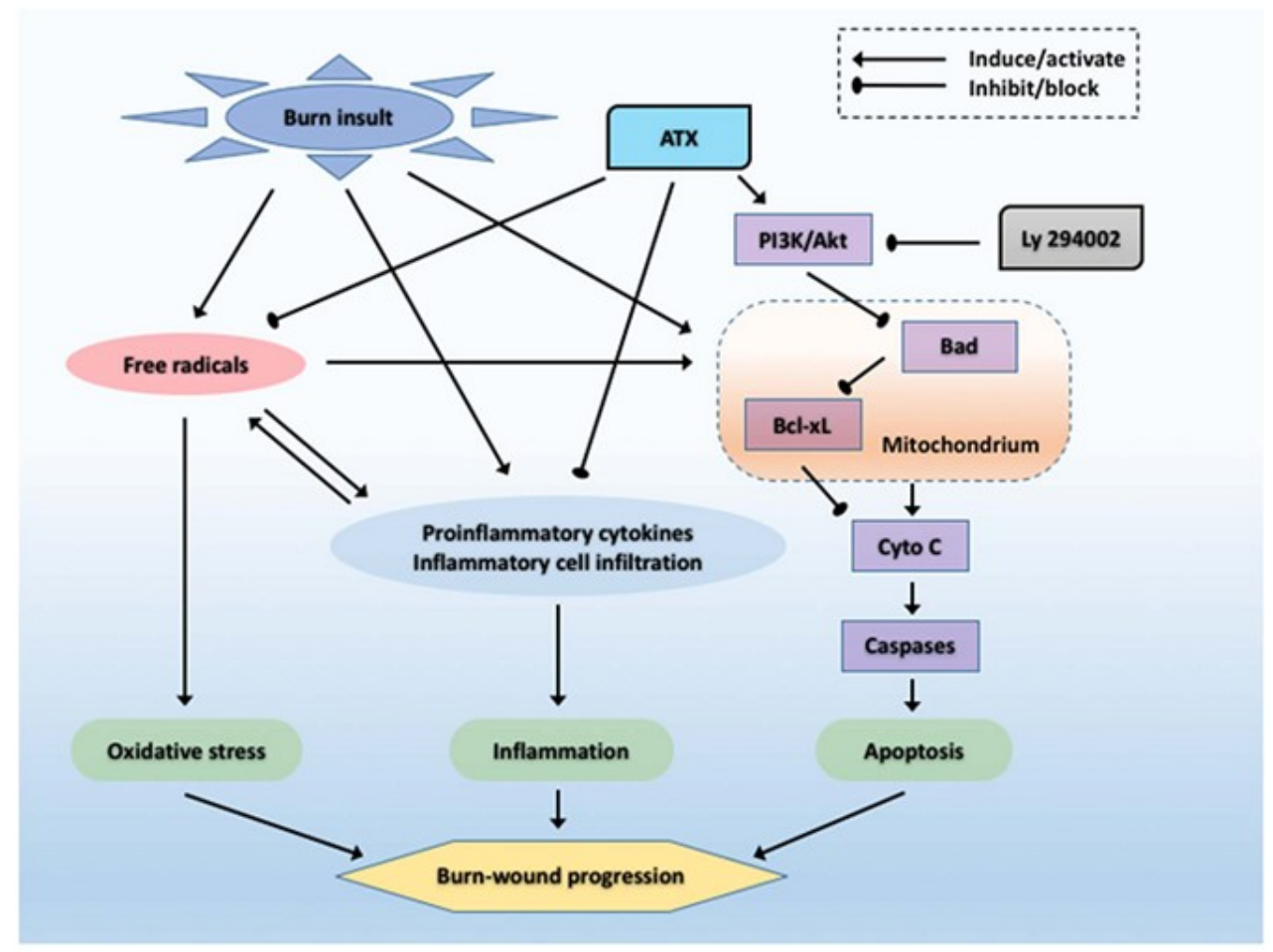

Gambar 5. Diagram skematik efek potensial astaxanthin. Keterangan: Astaxanthin (ATX), cytochrome C (Cyto C). ${ }^{2}$

Dalam naskah ini, yang ditinjau pertama adalah efek potensial ATX pada perkembangan luka bakar. Hasil menunjukkan sebagai berikut: 1) ATX meringankan perubahan histologis yang disebabkan oleh luka bakar; 2) Dosis dependen ATX mengurangi stres oksidatif selama tahap awal setelah luka bakar sebagai respons terhadap produksi radikal bebas dengan menghambat peroksidasi lipid dan aktivasi sistem oksidase yang tergantung NADPH dan dengan meningkatkan aktivitas enzim antioksidan endogen; 3) Astaxanthin dapat meredakan inflamasi pada tahap awal luka bakar; dan 4) meningkatkan dosis ATX lebih lanjut dapat mengurangi apoptosis sel di zona stasis dengan mempengaruhi jalur apoptosis terkait mitokondria (Gambar 5). ${ }^{2}$

Studi oleh Meephansan et al. (2017) menyatakan efek penyembuhan luka dipercepat dengan astaxanthin topikal, diamati pada hari pertama setelah cedera, selama fase inflamasi. Efek ini dapat dimediasi baik oleh supresi tingkat inflamasi atau oleh percepatan tahap inflamasi. Inflamasi minimal diketahui berkontribusi untuk penyembuhan luka yang lebih baik. Astaxanthin dapat menekan inflamasi melalui berbagai mekanisme. Pertama, efek ini bisa difasilitasi dengan keseimbangan stres oksidatif, sedangkan produksi ROS pada fase awal jauh lebih tinggi daripada normal untuk mempertahankan diri dari serangan mikroorganisme dan mengirimkan sinyal antar sel yang mendukung proses peradangan, astaxanthin mengambil ROS dan RNS yang berlebihan, yang konsisten dengan hasil penelitian yang menunjukkan ekspresi menurun secara signifikan inducible nitric oxide synthase (iNOS), penanda stres oksidatif, pada kelompok yang diberi astaxantin. Hasilnya, aktivasi jalur NF-kB dapat dicegah, yang mengarah ke pengurangan proinflamasi transkripsi gen dan produksi sitokin proinflamasi. 
Hasilnya, aktivasi jalur NF-kB dapat dicegah, yang mengarah ke pengurangan proinflamasi transkripsi gen dan produksi sitokin proinflamasi. Kedua, astaxanthin mungkin memiliki efek penghambatan pada ekspresi molekul adhesi. Sumber utama ROS selama inflamasi adalah NADPH oksidase dalam plasma membran neutrofil dan makrofag. Studi tersebut menemukan bahwa antioksidan tradisional menekan ekspresi adhesi molekul intercellular adhesion molecule 1 (ICAM-1), vascular cell adhesion molecule 1 (VCAM-1), E-selectin dan IL-8 selama inflamasi. Astaxanthin juga dapat menghambat ekspresi molekul-molekul tersebut, yang mengarah ke penghambatan infiltrasi sel inflamasi. Produksi ROS di mitokondria ditemukan terlibat dalam jalur sinyal inflamasi, dan efek perlindungan dari astaxanthin juga melindungi terhadap molekul oksidatif intraseluler ini. Selain itu, aktivitas antikomplemen juga dapat terlibat dalam supresi inflamasi. ${ }^{19}$

Hasil selama fase proliferasi dan remodeling juga menunjukkan potensi signifikan astaxanthin untuk mengurangi ukuran luka selama proses penutupan. Ini berkorelasi dengan peningkatan ekspresi basic fibroblast growth factor (bFGF). bFGF berperan penting dalam pembentukan jaringan granulasi, reepitelisasi, matriks formasi, dan remodeling, yang merupakan peristiwa besar selama fase proliferasi dan remodeling. Studi in vitro telah menunjukkan bahwa bFGF mengatur sintesis dan deposisi berbagai komponen extra cellular matrix (ECM), meningkatkan motilitas keratinosit selama reepitelisasi, mempromosikan migrasi fibroblas, dan merangsang mereka untuk menghasilkan kolagenase. Meningkatnya ekspresi bFGF mRNA pada kelompok yang diberi astaxanthin selama fase awal penyembuhan luka dapat berkontribusi pada percepatan penutupan luka yang signifikan. ${ }^{19}$

Penelitian menunjukkan ekspresi marker biologi penyembuhan luka lainnya yaitu collagen type 1 alpha 1 (Col1A1) lebih tinggi pada hari 6 setelah cedera pada kelompok yang diobati dengan astaxanthin, dibandingkan dengan grup kontrol. Hal ini konsisten dengan studi tentang penyembuhan luka, yang menyebutkan bahwa astaxanthin meningkatkan ekspresi Col1A1. Kontraksi luka adalah mekanisme lain yang penting dalam proses penutupan luka, terutama pada hewan pengerat. Astaxanthin mempercepat kontraksi luka selama fase proliferasi dan maturasi dengan meningkatkan fungsi miofibroblas, sel-sel yang berdiferensiasi dari fibroblas jaringan, yang memainkan peran kunci dalam proses ini. Fitur otot polos miofibroblas menghasilkan kekuatan kontraktil antara tepi luka dan ECM. Miofibroblas juga menghasilkan matriks kolagen untuk membentuk jaringan parut, dan melepaskannya sitokin dan faktor pertumbuhan berkontribusi terhadap peningkatan laju penyembuhan luka. Namun, pada tahap selanjutnya, miofibroblas dikeluarkan dari luka yang sembuh normal. Akumulasi yang persisten dapat menyebabkan skar hipertrofik atau keloid. Dalam penelitian Meephansan et al. (2017), tidak ada bekas luka yang terlihat pada akhir penelitian pada kedua kelompok. Selain meningkatkan kontraksi luka, astaxanthin juga dapat mengurangi kemungkinan fibrosis dengan menginduksi apoptosis miofibroblas dan atau menekan TGF- $\beta .{ }^{19-21}$

\section{Kesimpulan}

Luka bakar dapat terjadi karena paparan panas dan bahan kimia.. Pada luka bakar, reaksi inflamasi akut berkepanjangan didominasi oleh neutrofil dan makrofag yang dapat menaikkan level sitokin proinflamasi. Hal ini berkontribusi salah satunya pada produksi oksigen radikal bebas yang mengakibatkan gangguan membran plasma, ikatan silang dan putusnya ikatan DNA, serta fragmentasi peptide. Reaksi stres oksidatif ini dapat 
ditekan dengan agen antioksidan astaxanthin yang merupakan antioksidan alami. Astaxanthin meredakan inflamasi pada tahap awal luka bakar dan mengurangi apoptosis sel di zona stasis. Pengobatan topikal dengan ekstrak astaxanthin tampaknya mempercepat penyembuhan luka pada luka full-thickness pada tikus. Penelitian selanjutnya cenderung menggunakan astaxanthin sebagai strategi berbasis redoks untuk mengobati luka pada manusia.

\section{Daftar Pustaka}

1. Lloyd EC, Rodgers BC, Michener M, Williams MS. Outpatient Burns: Prevention and Care. American Family Physician. 2012; 85(1):25-32.

2. Fang $Q$, Guo $S$, Zhou $H$, Han $R$, Wu $P$, Han C. Astaxanthin Protects Against Early Burn-Wound Progression in Rats by Attenuating Oxidative Stress-Induced Inflammation and Mitochondria-Related Apoptosis. Scientific Reports. 2017; 7:41440.

3. Chow O, Barbul A. Immunonutrition: Role in Wound Healing and Tissue Regeneration. Advances in Wound Care. 2014; 3 (1):46-53.

4. Pries AR, Secomb TW. Making Microvascular Networks Work: Angiogenesis, Remodeling, and Pruning. Physiology. 2014; 29(6):446-55.

5. Evers LH, Bhavsar D, Mailander P. The Biology of Burn Injury. Experimental Dermatology. 2010; 19(9):777-83.

6. Levi B, Wang S. Burns. In: Kang S, Amagai M, Bruckner AL, Enk AH, Margolis DJ, Mcmichael AJ, Orringer JS (Editors). Fitzpatrick's Dermatology in General Medicine. 9th ed. 2019. New York: McGraw Hill Co. P.1679-91.

7. Perez E, Foley M, Karlin R (Reviewer). Classifications of Burns. New York: University of Rochester Medical Center Rochester. (Internet), 2021. Available from: https://www.urmc.rochester.edu/ encyclopedia/content.aspx? contenttypelD=90\&content ID=P09575.

8. Jackson DM. The Diagnosis of the Depth of Burning. Br J Surg. 1953; 40:588-96.

9. Shupp JW, Nasabzadeh TJ, Rosenthal DS, Jordan $M H$, Fidler $P$, Jeng JC. A Review of the Local Pathophysiologic Bases of Burn Wound Progression. Journal of Burn Care \& Research. 2010; 31(6):849-73.

10. Gravante G, Filingeri V, Delogu D, et al. Apoptotic Cell Death in Deep Partial Thickness Burns by Coexpression Analysis of TUNEL and Fas. Surgery. 2006; 139:854-5.

11. Gravante G, Delogu D, Palmieri MB, Santeusanio G, Montone A, Esposito G. Inverse Relationship between the Apoptotic Rate and the Time Elapsed from Thermal Injuries in Deep Partial Thickness Burns. Burns. 2008; 34:22833.

12. Zheng YF, Bae SH, Kwon MJ, Park JB, Choi HD, Shin WG, Bae SK. Inhibitory Effects of Astaxanthin, $\beta$-Cryptoxanthin, Canthaxanthin, Lutein, and Zeaxanthin on Cytochrome P450 Enzyme Activities. Food and Chemical Toxicology. 2013; 59:78-85.

13. Baralic I, Andjelkovic M, Djordjevic B, Dikic N, Radivojevic N, Suzin-Zivkovic V, Radojevic-Skodric S, Pejic S. Effect of Astaxanthin Supplementation on Salivary IgA, Oxidative Stress, and Inflammation in Young Soccer Players. Evidence-Based Complementary and Alternative Medicine. 2015; 2015. Article ID 783761.

14. Yuan JP, Peng J, Yin K, Wang JH. Potential Health-Promoting Effects of Astaxanthin: A high-Value Carotenoid Mostly from Microalgae. Molecular Nutrition \& Food Research. 2011; 55 (1):150-65. 
15. Fakhri S, Abbaszadeh F, Dargahi L, Jorjani M. Astaxanthin: A Mechanistic Review on Its Biological Activities and Health Benefits. Pharmacological Research. 2018; 136:1-20.

16. Dong $S$, Huang $Y$, Zhang R, Wang $S$, Liu $Y$. Four Different Methods Comparison for Extraction of Astaxanthin from Green Alga Haematococcus pluvialis. The Scientific World Journal. 2014; 2014. Article ID 694305.

17. Ranga Rao A. Production of Astaxanthin from Cultured Green Alga Haematococcus pluvialis and its Biological Activities. Doctoral Dissertation. India: University of Mysore. 2011.

18. Dong LY, Jin J, Lu G, Kang XL. Astaxanthin Attenuates the Apoptosis of Retinal Ganglion Cells in $\mathrm{db} / \mathrm{db}$ Mice by Inhibition of Oxidative Stress. Marine Drugs.
2013;11(3):960-74.

19. Meephansan J, Rungjang A, Yingmema W, Deenonpoe R, Ponnikorn S. Effect of Astaxanthin on Cutaneous Wound Healing. Clinical, Cosmetic and Investigational Dermatology. 2017; 10:259.

20. Wang M, Zhang J, Song X, Liu W, Zhang L, Wang X, Lv C. Astaxanthin Ameliorates Lung Fibrosis In Vivo and In Vitro by Preventing Transdifferentiation, Inhibiting Proliferation, and Promoting Apoptosis Of Activated Cells. Food and Chemical Toxicology. 2013; 56:450-8.

21. Shen $M$, Chen $K, L u J$, Cheng $P, X u L$, Dai W, Wang F, He L, Zhang Y, Chengfen W, Li J. Protective Effect of Astaxanthin on Liver Fibrosis through Modulation of TGF-1 Expression and Autophagy. Mediators of Inflammation. 2014; 2014. Article ID 954502. 